\title{
Lipid-rich fraction of the sclerotium of Tiger Milk Mushroom Lignosus rhinocerotis (Agaricomycetes) attenuates LPS-induced inflammation in BV2 cells via Nrf2 pathway
}

\author{
Neeranjini Nallathamby ${ }^{\oplus a, b}$, Hariprasath Lakshmanan ${ }^{a, c}$, Sharmili Vidyadarana,d, \\ Sri Nurestri Abdul Malek ${ }^{\mathrm{a}}$, Chia-Wei Phan ${ }^{\mathrm{a}, \mathrm{e}}$ and Vikineswary Sabaratnam ${ }^{\mathrm{a}, \mathrm{b}, *}$
}

\author{
${ }^{a}$ Mushroom Research Centre, University of Malaya, 50603 Kuala Lumpur, Malaysia, ${ }^{b}$ Institute of \\ Biological Sciences, Faculty of Science, University of Malaya, 50603 Kuala Lumpur, Malaysia, \\ ${ }^{c}$ Department of Biochemistry, Karpagam Academy of Higher Education, Coimbatore - 641 \\ 021, Tamil Nadu, India, 'Immunology Laboratory, Faculty of Medicine and Health Sciences, \\ Universiti Putra Malaysia,43400 Serdang, Malaysia, ${ }^{e}$ Department of Pharmaceutical Life \\ Sciences, Faculty of Pharmacy, University of Malaya, 50603 Kuala Lumpur, Malaysia
}

\begin{abstract}
Lignosus rhinocerotis (tiger milk mushroom) is widely used by the indigenous people of Malaysia as a traditional remedy. The present study was carried out in order to evaluate the antioxidant, cytotoxic and anti-neuroinflammatory activities of L. rhinocerotis extract on brain microglial cells (BV2). The antioxidant activity was evaluated by 2,2-diphenyl-1-picryhydrazyl (DPPH•), 2,2'-azinobis (3-ethylbenzthiazoline-6-sulphonic acid) (ABTS•+) scavenging assays, and ferric reducing antioxidant

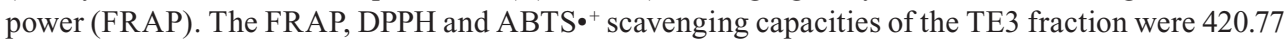
$\mathrm{mg} \mathrm{FE} / \mathrm{g}, 58.01 \%$, and $7 \%$, respectively. The cytotoxic activity was determined by MTS assay. The in vitro model of anti-neuroinflammatory property was evaluated by measuring the production of nitric oxide (NO) in lipopolysaccharide (LPS)-induced BV2 cells. The TE3 fraction showed a significant NO reduction at 1 to $100 \mu \mathrm{g} / \mathrm{mL}$. The TE3 fraction down-regulated inducible nitric oxide synthase (iNOS) and cyclooxygenase-2 (COX2) genes while it upregulated heme oxygenase (HO-1) and NADPH quinone acceptor oxidoreductase-1 (NQO-1) genes. The nuclear factor (erythroid-derived 2)-like 2 (Nrf2) transcription was also activated. The chemical component of the active fraction (TE3) was identified by gas chromatography-mass spectrometry (GCMS). Overall, the BV2 in vitro model anti-neuroinflammatory activity of $L$. rhinocerotis may be caused by the lipid constituents identified in the fraction.
\end{abstract}

Keywords: Neuroinflammation. Lignosus rhinocerotis. Mushroom. BV2 cells. Nrf2 pathway.

\section{INTRODUCTION}

Free radicals are important in the regulation gene expression and activation of receptors. However, an excess of free radicals is toxic and able to damage functional molecules during oxidative stress (Xu et al., 2009). This

*Correspondence: V. Sabaratnam. Mushroom Research Centre, University of Malaya, 50603 Kuala Lumpur, Malaysia. Phone: 03-7967 6703. viki@ um.edu.my can lead to many diseases such as cancer, age-related disorders, neurodegenerative diseases and inflammation (Diaz et al., 2012). Several anti-inflammatory and neuroprotective drugs have been shown to have an antioxidant and/or anti-radical scavenging mechanism as part of their activities. Functional foods that contain different types of antioxidants and their total antioxidant capacities (TAC) to scavenge free radicals, would be useful since neurodegenerative disease are caused by cellular oxidative stress. 
Inflammation of the brain is characterised by the activation of glial cells (mainly microglial and astrocytes), expression of inflammatory mediators, and release of neurotoxic free radicals (Chen et al., 2016). This phenomenon is collectively known as "neuroinflammation". Emerging evidence indicates that neuroinflammation is closely associated with neurodegenerative disorders in both acute (stroke, injury) and chronic diseases (multiple sclerosis, Alzheimer's, and Parkinson diseases) (McManus, Heneka, 2017).

Lignosus rhinocerotis (Cooke) Ryvarden, better known as the "tiger milk mushroom" in Southeast Asia, has been used as a folk medicine for many years (Seow et al., 2015). Previous studies have attempted to validate the anti-cancer activities and its anti-inflammatory properties of sclerotium of L. rhinocerotis, (Lau et al., 2015; Lee et al., 2012; Nallathamby et al., 2018). However, there is less validation of bioactive compounds on its anti-neuroinflammatory effect on in vitro BV2 model. Therefore, this study is aimed towards elucidating the bioactive fraction of ethyl acetate (TE3) fraction of $L$. rhinocerotis with respect to its a) chemical components; b) cytotoxicity and the inhibition of nitric oxide (NO) production in BV2 cells; and c) effects on gene expression in the nuclear factor-erythroid 2-related factor $2(\mathrm{Nrf} 2)$ pathway.

\section{MATERIAL AND METHODS}

\section{Sample preparation}

Freeze dried sclerotium of $L$. rhinocerotis commercial cultivar powder (TM02) was purchased from Ligno Biotech, Selangor, Malaysia. The freezedried powder $(1 \mathrm{~kg})$ was extracted with $80 \%$ ethanol. The ethanol extract was further fractionated with ethyl acetate as previously reported in Nallathamby et al. (2016). The extract was concentrated on a rotary evaporator at $45^{\circ} \mathrm{C}$ (Buchi, Switzerland) under reduced pressure. The ethyl acetate extract $(5 \mathrm{~g})$ was subjected to vacuum liquid chromatography and eluted with a mixture of $n$-hexane: acetone in an increasing amount of acetone. The third fraction (TE3) out of the total seven fractions collected was further analysed (Kanagasabapathy et al., 2011).

\section{Ferric reducing antioxidant power (FRAP) assay}

The FRAP assay was performed using the method described by Nallathamby et al. (2016). FRAP reagent was prepared by mixing $50 \mathrm{~mL}$ of $300 \mathrm{mM}$ acetate buffer; $5 \mathrm{~mL}$ of $10 \mathrm{mM}$ 2,4,6-tripyridyl-s-triazine solution (TPTZ) in $40 \mathrm{mM}$ of hydrochloric acid $(\mathrm{HCl})$ and $5 \mathrm{~mL}$ of $20 \mathrm{mM}$ ferric chloride $\left(\mathrm{FeCl}_{3} \cdot 6 \mathrm{H}_{2} \mathrm{O}\right)$ in the ratio of 10:1:1. FRAP reagent $(300 \mu \mathrm{L})$ was added to $10 \mu \mathrm{L}$ of TE 3 fraction plated in a flat bottomed 96 well microtiter plates and absorbance was measured at $593 \mathrm{~nm}$ after $4 \mathrm{~min}$. The standard used was iron sulfate $\left(\mathrm{FeSO}_{4}\right)$. The FRAP results are mean values of triplicate assays and were expressed in $\mathrm{mM} \mathrm{FeSO}_{4}$ equivalent (FSE) per gram mushroom (mmol FSE/g TE 3 fraction).

\section{Trolox equivalent antioxidant capacity (TEAC) assay}

2,2'-Azino-bis(3-ethylbenzothiazoline-6-sulfonic) acid $\left(\mathrm{ABTS}^{\bullet}{ }^{+}\right)$is a stable radical cation used to measure TEAC. The ABTS ${ }^{+}$reagent was prepared by mixing 5 $\mathrm{mL}$ of $7 \mathrm{mM} \mathrm{ABTS} \bullet^{+}$solution with $89 \mu \mathrm{L}$ of $140 \mathrm{mM}$ $\mathrm{K}_{2} \mathrm{~S}_{2} \mathrm{O}_{8}$. It was kept in the dark at room temperature for $16 \mathrm{~h}$ and the absorbance of the ABTS ${ }^{+}$reagent was adjusted to $0.70 \pm 0.05$ at $734 \mathrm{~nm}$ prior to assay. Trolox was used as the standard. The ABTS $\bullet^{+}$reagent $(100 \mu \mathrm{L})$ was added to $10 \mu \mathrm{L}$ of the TE 3 fraction in flatbottomed 96 well microtiter plates. The absorbance was measured at $734 \mathrm{~nm}$ after 1 minute. TEAC values were mean values of triplicates assay and were expressed in ABTS $^{+}{ }^{+}$scavenged percentage (\%). (Nallathamby et al., 2016)

\section{Diphenyl-1-picryl-hydrazyl (DPPH) radical scavenging assay}

The TE 3 fraction $(5 \mu \mathrm{L})$ was mixed with $195 \mu \mathrm{L}$ of methanolic solution containing DPPH radical in flatbottomed 96 well microtiter plates. The mixture was shaken vigorously and left to stand for $3 \mathrm{~h}$ in the dark, and the absorbance was measured at $515 \mathrm{~nm}$. Ascorbic acid was used as standard. The assay was carried out in triplicates and DPPH activity was expressed in DPPH inhibition percentage (\%). (Nallathamby et al., 2016)

\section{BV2 cell culture}

BV2 cells were presented by Dr. Sharmili from the Immunology Laboratory in UPM, Malaysia. BV2 cells were maintained in Dulbecco Modified Eagle medium (DMEM) supplemented with 5\% heat-inactivated fetal bovine serum (FBS), $100 \mathrm{U} / \mathrm{mL}$ penicillin, $100 \mu \mathrm{g} /$ $\mathrm{mL}$ streptomycin, $1 \mathrm{~mL} / \mathrm{L}$ gentamycin, $250 \mu \mathrm{g} / \mathrm{mL}$ 
fungizone, $1 \times$ non-essential amino acids, $2 \mathrm{mg} / \mathrm{mL}$ insulin, and $1.5 \mathrm{~g} / \mathrm{L}$ sodium bicarbonate. Cultures were maintained at $37{ }^{\circ} \mathrm{C}$ in $95 \%$ humidified air and 5\% CO2. Cells were harvested by treating with $0.25 \%$ trypsin in 1 mM EDTA for 5 min at $37^{\circ} \mathrm{C}$.

\section{Cell viability assay}

The cytotoxic effects of the fraction were determined by using 3-(4,5-dimethylthiazol-2-yl)-5(3-carboxymethoxyphenyl)-2-(4-sulfophenyl)-2 $\mathrm{H}$ tetrazolium (MTS) assay (Tan et al., 2011). In a flatbottomed 96 -well microtiter plate, $5 \times 10^{4}$ cells were seeded per well and incubated at $37{ }^{\circ} \mathrm{C}$ overnight for attachment. To determine cytotoxic effect, cells were incubated for 24 hours with different concentrations of TE 3 fraction $(0.01-1000 \mu \mathrm{g} / \mathrm{mL})$. To determine the protection effect, cells were incubated for 24 hours with different concentrations of TE3 fraction (0.01$1000 \mu \mathrm{g} / \mathrm{mL}$ ) and $1 \mu \mathrm{g} / \mathrm{mL}$ of Escherichia coli (O55:B5) lipopolysaccharide (LPS). After $24 \mathrm{~h}$ incubation, MTS solution was added and further incubated for $2 \mathrm{~h}$. The absorbance was measured at $490 \mathrm{~nm}$ with a microplate reader (Dynex MRX II microplate reader, USA). Each assay was performed in triplicates. Cell viability was calculated in comparison to the untreated cells.

\section{Nitric oxide (NO) determination assay}

Nitrite that accumulated in the culture medium was measured as an indicator of $\mathrm{NO}$ production based on the Griess reaction (Ozcelik, Algul, 2017). The BV2 cells were seeded in a 96-well plate at a density of $5 \times 10^{4}$ cells/well and incubated overnight. Cells were then incubated with different concentrations of TE3 fraction $(0.01-1000 \mu \mathrm{g} / \mathrm{mL})$ and $1 \mu \mathrm{g} / \mathrm{mL}$ of Escherichia coli
(O55:B5) lipopolysaccharide (LPS) (Sigma, US). After $24 \mathrm{~h}$, the culture supernatant was collected for nitrite measurement. $50 \mu \mathrm{L}$ of the spent medium was plated in flat-bottomed 96 well microtiter plates and $50 \mu \mathrm{L}$ of Griess reagent $(0.1 \% N$-1-[naphthyl] ethylenediaminediHCl, $1 \%$ sulphanilamide and $2.5 \% \mathrm{H}_{3} \mathrm{PO}_{4}$ ) was added. The plate was incubated for $15 \mathrm{~min}$, and the absorbance was measured at $530 \mathrm{~nm}$. The amount of NO was calculated using a sodium nitrite standard curve.

\section{RNA extraction and quantitative real time PCR}

The BV2 cells were lysed and the total RNA was extracted as recommended by the manufacturer's manual using an Ambion-RNAqueous Micro ${ }^{\circledR}$ kit (Applied Biosystems, USA). cDNA was synthesised from the purified RNA using the High Capacity cDNA Reverse Transcription Kit (Applied Biosystems, USA). The reaction setup for all quantitative real time PCR (qPCR) reactions was performed according to the reaction setup instructions generated by the StepOne software (Ver 2.0, Applied Biosystems). The reactions were carried out with TaqMan ${ }^{\circledR}$ probes (Applied Biosystems, USA) in a reaction volume of $20 \mu \mathrm{L}$. Briefly, the reaction which consisted of the TaqMan ${ }^{\circledR}$ Gene Expression Master Mix and the assay mix were prepared separately. Each assay mix contained corresponding primers and probe for each targeted gene. Each reaction was assayed in triplicate. The reaction mix was mixed with either sterile ultrapure water for no template control reactions (NTC) or the isolated cDNA. The strips were centrifuged and loaded into the real time PCR thermal cycler (StepOnePlusTM Real Time PCR System). The relative expression of the investigated genes was normalised with the endogenous control, $\beta$ actin rRNA. Table I shows the list of genes investigated.

TABLE I - List of genes investigated

\begin{tabular}{cccc}
\hline No & Gene name & Abbreviation & Assay ID* \\
\hline 1. & Nuclear factor (erythroid-derived 2)-like 2 & NFE212/ & Mm00477784_m1 \\
2. & HRF2 & HO-1 & Mm00516005_m1 \\
3. & NAD (P)H quinone oxidoreductase 1 & NQO-1 & Mm01253561_m1 \\
4. & Inducible nitric oxide synthase & NOS2 & Mm00440502_m1 \\
5. & Beta- actin & $\beta$-actin & Mm00607939_s1 \\
\hline
\end{tabular}


TABLE I - List of genes investigated

\begin{tabular}{cccc}
\hline No & Gene name & Abbreviation & Assay ID* \\
\hline 6. & Cyclooxigenase- 2 & COX-2 & Mm00478374_m1 \\
\hline
\end{tabular}

*Note: Assay ID refers to the Applied Biosystems Gene Expression Assay kits with proprietary primer and TaqMan ${ }^{\circledR}$ probe mix. Mn: Mus musculus

\section{Gas chromatography-mass spectrometry (GC-MS) analysis}

GC-MS analysis was performed using an Agilent Technologies $6890 \mathrm{~N}$ (United States) gas chromatograph equipped with a 5979 Mass Selective Detector $(70 \mathrm{eV}$ direct inlet) and a HP-5 ms (5\% phenylmethylpolysiloxane) capillary column $(30 \mathrm{~m} \times 0.25 \mathrm{~mm}$ i.d. x $0.25 \mu \mathrm{m}$ film thickness). The oven temperature was initially set at $100^{\circ} \mathrm{C}$, and then increased at the rate of $5^{\circ} \mathrm{C}$ per minute to $300{ }^{\circ} \mathrm{C}$. Helium was used as the carrier gas at a flow rate of $1 \mathrm{~mL} / \mathrm{min}$. The total ion chromatogram obtained was auto-integrated by Chemstation and the constituents were identified by comparison with those in the mass spectral library (W9N11. Mass Spectrum Library, USA, 2011).

\section{Statistical Analysis}

All data triplicates were recorded as means \pm standard deviation (SD) and analysed by SPSS for Windows (version 18). One-way analysis of variance (ANOVA) and Dunnett comparisons were carried out to test any significant differences. $\mathrm{P}<0.05$ was considered statistically significant.

\section{RESULTS AND DISCUSION}

\section{Antioxidant activity of TE3 fraction}

The ferric reduction power of the TE3 fraction was $420.77 \mathrm{mg} \mathrm{FE} / \mathrm{g}$ TE 3 fraction. The ABTS radical scavenging capacity of the TE3 fraction was about $7 \%$ while the DPPH scavenging activity was $58.01 \%$. The TE3 fraction possessed moderate antioxidant activities compared to the standard antioxidant compounds used. The antioxidant activities of the extract were lower than the antioxidant activities of the standard antioxidant compound used. The extract could only achieve $\mathrm{IC}_{50}$ at a higher concentration compared to the standard compounds. The antioxidant results of the TE3 extract and the standard compounds are shown in Table I. Undesirable oxidation increases the reactive oxygen species (ROS) creating oxidative stress which leads to inflammation if prolonged. The components in the cells (protein and lipid) will increase and defend against ROS and restore the balance in the cells (Hensley et al., 2000). A study by Babbar et al., (2011) also showed that phenolic compounds alone are not fully responsible for the antioxidant activity. Other constituents such as ascorbates, lipids, terpenes, and pigments as well as the synergistic effect among them could possibly contribute to the totality of antioxidant activity.

\section{Effect of TE3 fraction on cell viability of BV2 cells}

The effect of the TE3 fraction of L. rhinocerotis on the viability of BV2 cells at various concentrations was determined by MTS assay. The cytotoxicity and protective effects of the TE3 fraction are shown in Figure 1a. The cell viability of the untreated BV2 cells was indicated as $100 \%$. The negative control is labelled LPS and the positive control is labelled LNAME. The TE3 fraction did not exert any cytotoxic effect on BV2 cells at $0.1-100 \mu \mathrm{g} / \mathrm{mL}$ concentrations. The TE3 fraction also did not exert any cytotoxic effect on LPS induced BV2 cells at $0.1-100 \mu \mathrm{g} / \mathrm{mL}$ concentrations. The protective effects of TE3 fractions were done to show its ability to protect and prevent cell deaths of the LPS induced BV2 cells (inflamed microglial). Thus, the TE3 fraction was not cytotoxic towards the BV2 cells and was also able to protect the BV2 cells after being inflamed.

Similar to our findings, the ethanol extract of Euphorbia hirta (Sharma et al., 2014) indicated no adverse effect on RAW 264.7 cells with concentrations up to $200 \mu \mathrm{g} / \mathrm{mL}$, while the conjugated linoleic acid (Cheng et al., 2004) had no cytotoxic effect up to $200 \mu \mathrm{M}$, respectively. 

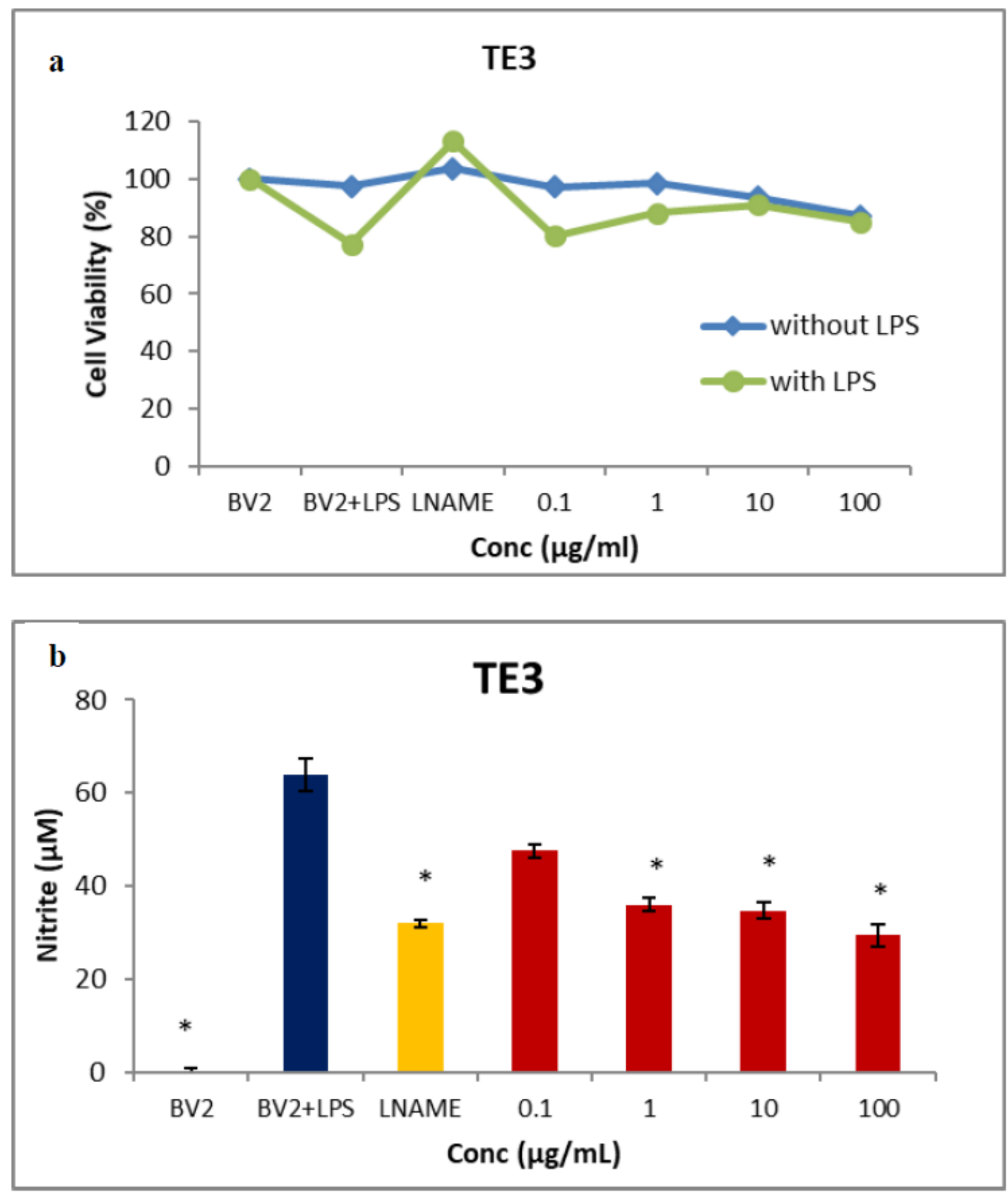

Figure 1 - The effect of treatment with the TE3 fraction of L. rhinocerotis on (a) BV2 cell viability and (b) nitrite production in BV2 cells. The * symbol denotes a significant difference $(\mathrm{p}<0.05)$ from the corresponding value of the control. L-NAME= $\mathrm{N}(\omega)$-nitro-L-arginine methyl ester $(200 \mu \mathrm{M})$. 


\section{Effect of TE3 fraction on nitric oxide production in LPS stimulated BV2}

The effect of $L$. rhinocerotis TE3 fraction (0.1 to $100 \mu \mathrm{g} / \mathrm{mL}$ concentrations) on NO production by LPS-stimulated BV2 cells was tested as shown in Figure 1b. In unstimulated BV2 cells, the basal levels of NO were detected while LPS stimulation of the cells resulted in an increase in NO production, which is denoted as $63.9 \mu \mathrm{M}$. A dose-dependent inhibition of NO production in BV2 cells was observed from 1 to $100 \mu \mathrm{g} / \mathrm{mL}$ concentrations when treated with the TE3 fraction. A significant $(\mathrm{p}<0.05)$ reduction of NO production by BV2 cells with TE3 treatment was observed from 1 to $100 \mu \mathrm{g} / \mathrm{mL}$ with inhibition ranging from $43 \%$ to $54 \%$.

Microglia are distributed in the CNS and activated cells release proinflammatory mediators such as NO and reactive oxygen species (ROS) (GonzalezScarano, Baltuch, 1999). Regulation of chronic inflammation of microglia is to prevent the onset inflammation related neurodegenerative diseases. The TE3 fraction has anti-inflammatory properties that significantly $(p<0.05)$ decrease NO production without exerting cytotoxic effects. The results of this study correspond to previous studies done on antiinflammatory and anti-neuroinflammatory activities of mushrooms and plants. The results of the current study had a similar NO reduction compared with Ganoderma lucidum terpene extract (GLT) which significantly reduced $\mathrm{NO}$ levels with the $\mathrm{IC}_{50}$ being $11.4 \mu \mathrm{g} / \mathrm{mL}$ (Dudhgaonkar et al., 2009). Oleamide (Oh et al., 2010) significantly inhibited NO production in BV2 cells, while palmitic acid (Lee et al., 2010) inhibited NO in peritoneal machrophages both at $10 \mu \mathrm{M}$. However, the TE3 fraction inhibited NO production at a lower concentration compared to these compounds. This suggested that the TE3 fraction had higher anti-inflammatory activity than its individual compounds. This indicated a combination synergestic effect of the components.

\section{Effect of TE3 fraction on the relative expression levels of inflammatory genes in LPS stimulated BV2 cells}

In the present study, microglial BV2 cells were stimulated with lipopolysaccharide (LPS) $(1 \mu \mathrm{g} / \mathrm{mL})$ in the presence of non-cytotoxic concentrations of the TE3 fraction; and the level of induced nitric oxide synthase (iNOS) and cyclooxygenase 2 (COX2) expressions were measured as shown in Figures $2 \mathrm{a}$ and $2 \mathrm{~b}$. The expression of proinflammatory genes, i.e. iNOS and COX2 after LPS stimulation increased by 1.5 -fold and 1.8-fold; respectively, when compared to the controls (unstimulated BV2 cells). Treatment with the TE3 fraction significantly $(p<0.05)$ decreased the iNOS gene expression by 1.18 -fold and the COX2 gene by 1.19 -fold. The suppression effects were higher compared to those of aspirin, which was the positive control.

The effects of the TE3 fraction on the expression of anti-inflammatory genes, i.e. heme oxygenase (HO-1) and NADPH: quinone acceptor oxidoreductase-1 (NQO1) were determined as shown in Figure $2 \mathrm{c}$ and Figure $2 \mathrm{~d}$. The TE3 fraction upregulated the expression of HO-1 and NQO-1 genes by 3.28- and 0.99-folds, respectively. The upregulation of HO-1 and NQO-1 by the TE3 fraction was comparable to the treatment with aspirin. The effect of thevTE3 fraction on Nrf2 expression was examined as shown in Figure 2e. Aspirin showed 1.40fold upregulation in the Nrf2 gene expression while the TE3-treated cells showed an upregulation of 1.49-fold.

Stimulation of microglial cells initiates the inflammatory responses by generating NO, iNOS, COX2, as well as other inflammatory mediators. Cumulative evidence indicates abnormalities or overproduction of these mediators may play a triggering role in many chronic inflammatory diseases (Musolino et al., 2017). Thus, suppression of these mediators and their functions serve as an effective therapeutic strategy for preventing or reducing inflammatory reactions and the related diseases. The transcription factor, Nrf2, is a controller of brain redox homeostasis and it regulates inflammatory conditions (Ma, 2013). It mediates the antioxidant response element (ARE) and cytoprotective genes. Nrf2-knockout-aged mice were highly sensitive to oxidative stress and more susceptible to the inflammatory response in the brain (Innamorato et al., 2008). Therefore, to target Nrf2 signalling could be a good strategy to reduce neuroinflammation. 


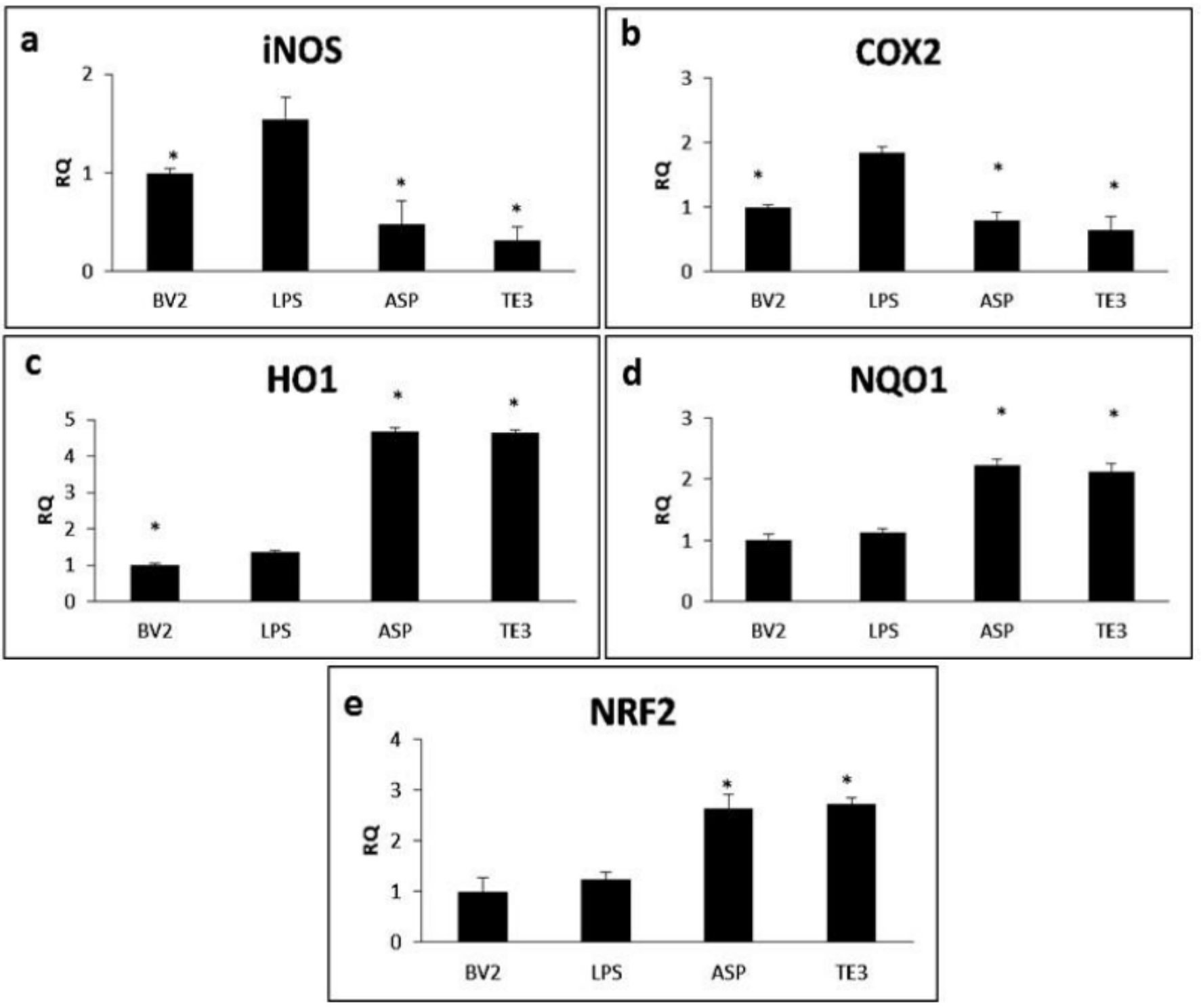

FIGURE 2A - The effect of different treatments in LPS stimulated BV2 cells on inflammatory genes; i.e. (a) iNOS, (b) COX2, (c) HO1, (d) NQO1, and (e) Nrf2. Fold increase values are calculated relative to the ACTB gene. BV2= untreated cells, LPS= LPS stimulated cells, ASP $=$ Aspirin $(100 \mathrm{uM})$, TE3 $=$ TE3 fraction $(10 \mu \mathrm{g} / \mathrm{mL})$ treatment in LPS stimulated BV2 cells. Data represent the mean $\pm \mathrm{SE}$ and from a representative of three independent experiments carried out in triplicates. The * symbol denotes a significant difference $(\mathrm{p}<0.05)$ from the corresponding value of the negative control (LPS). $R Q=$ relative quantification.

In the present study, the TE3 fraction attenuates microglial pro-inflammatory response by reducing $\mathrm{NO}$, the proinflammatory and anti-inflammatory cytokines via Nrf2 mediated pathway. The TE3 fraction upregulated HO-1 and NQO-1 and inhibited iNOS and COX2 expression in BV2 cells via Nrf2 which modulates their inflammatory responsiveness. Similar to our results, mollugin from Rubia cordifolia also demonstrated anti-inflammatory effects by suppressing $\mathrm{NO}$ and down-regulating iNOS and COX2 expressions (Jeong et al., 2011). 


\section{Identification of lipid constituent of TE3 fraction via GC-MS analysis}

Results from the GC-MS analysis are presented in Table II and Figure 3. The constituents in the TE3 fraction were identified by matching their massspectra with those in the accompanying mass-spectral library. Eight compounds were identified which made up $69.28 \%$ of the total components detected in the total ion chromatogram. Linoleic acid is the major component comprising of $45.35 \%$ of the total detected components. Other components identified were palmitic acid $(2.37 \%)$, oleamide $(7.12 \%)$, palmitamide $(3.50 \%)$, 4-hydroxybenzaldehyde (3.12\%) and its analogue 4-hydroxy-3-methoxybenzaldehyde (vanillin) (1.51\%), 9, 17-octadecadienal (3.36\%), and dehydroergosterol (2.96\%).

All mushrooms contain large amounts of essential fatty acids, especially linoleic acid. Essential fatty acids cannot be produced by animals but are required by the body for healing and good health (Wohl, Goodhart, 1968). The major component in this fraction is linoleic acid with $45.34 \%$. Many mushrooms analysed in previous studies had linoleic and palmitic acids as the most abundant fatty acids (Gunc-Ergönül et al., 2013). The results from this study are in agreement with previous reports that many mushrooms species have high abundance of unsaturated fatty acid especially linoleic acid (40\%-70\% of total lipid content) (Kalac, 2009; Phan et al., 2014). Linoleic acid had shown good anti-inflammatory activity comparable to its derivatives, i.e. $\alpha$-linolenic acid in human monocytic (THP-1) cells (Fritsche, 2015; Zhao et al., 2005). Some previous reports have shown linoleic acid has the property to be transported across the blood-brain barrier, thus it may be able to exert anti-neuroinflammation in the brain region (Edmond, 2001). Palmitic acid, a saturated long chain fatty acid commonly identified in mushrooms, is reported to modulate inflammation response and reduce cytokine effect in stimulated peritoneal macrophages (Lee et al., 2010).

The fatty acid amides, oleamide (7.12\%) and palmitamide $(3.50 \%)$ were present in this fraction. Oleamide is an amide of oleic acid; found accumulated in the cerebrospinal fluid of sleep-deprived animals and induces sedation and physiological sleep. Oh et al.

Table II - Chemical constituents of the TE3 fraction of ethyl acetate extract as determined by GC-MS

\begin{tabular}{|c|c|c|c|c|}
\hline Chemical constituent & RT(min) & Molecular formula & Molecular weight & Area \% \\
\hline 4-Hydroxy benzaldehyde & 8.423 & $\mathrm{C}_{7} \mathrm{H}_{6} \mathrm{O}_{2}$ & 122.12 & 3.12 \\
\hline Vanillin & 9.386 & $\mathrm{C}_{8} \mathrm{H}_{8} \mathrm{O}_{3}$ & 152.15 & 1.51 \\
\hline Palmitic acid & 21.409 & $\mathrm{C}_{16} \mathrm{H}_{32} \mathrm{O}_{2}$ & 256.42 & 2.37 \\
\hline Linoleic acid & 24.930 & $\mathrm{C}_{18} \mathrm{H}_{32} \mathrm{O}_{2}$ & 280.45 & 45.34 \\
\hline Palmitamide & 25.156 & $\mathrm{C}_{16} \mathrm{H}_{33} \mathrm{NO}$ & 255.44 & 3.50 \\
\hline Oleamide & 28.202 & $\mathrm{C}_{18} \mathrm{H}_{35} \mathrm{NO}$ & 281.48 & 7.12 \\
\hline 9,17-octadecadienal & 33.262 & $\mathrm{C}_{18} \mathrm{H}_{32} \mathrm{O}$ & 264.45 & 3.36 \\
\hline Dehydroergosterol & 39.774 & $\mathrm{C}_{28} \mathrm{H}_{42} \mathrm{O}$ & 394.63 & 2.96 \\
\hline Total & & & & 69.28 \\
\hline
\end{tabular}




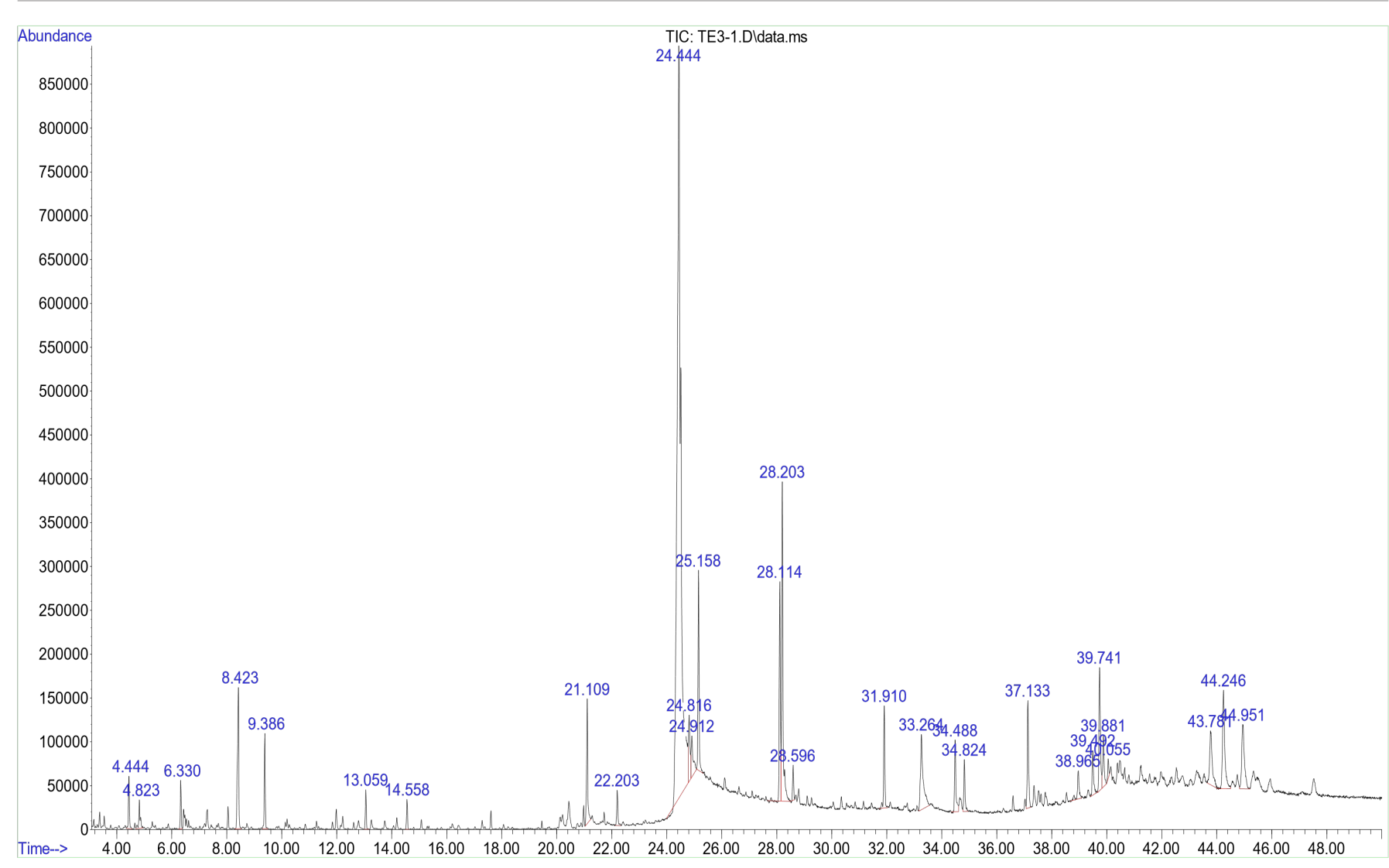

FIGURE 3 - GC-MS chromatogram of the TE3 fraction of ethyl acetate extract.

(2010) reported that oleamide suppressed LPS induced inflammation by lowering the expression of iNOS and COX-2. Palmitamide, also known as palmitic acid amide, has been shown to reduce prostate cancer progression (Liu et al., 2011).

The aldehyde components, 9, 17-octadecadienal, 4-hydroxy benzaldehyde, and its analogue 4-hydroxy3-methoxybenzaldehyde (vanillin), present have been accepted to be medicinally important by earlier research. The component 9, 17-octadecadienal is an unsaturated aldehyde is known for its antimicrobial activity (Rajeswari et al., 2013). Components 4-hydroxy benzaldehyde and vanillin are phenolic compounds that are commonly and majorly found in Gastrodia elata (family of Orchidaceae) and Vanilla planifolia. The 4-hydroxy benzaldehyde showed anti-inflammatory activity by suppressing NO, iNOS and COX 2 expressions, and ROS in murine macrophages (Lim et al., 2008). It has also inhibited COX2 expression and silica induced intracellular ROS (Lee et al., 2006). Vanillin is commonly used for its flavour and odour in food, beverages and cosmetics. Vanillin exhibits anti-inflammatory activity by inhibiting NFKB and COX2 expression (Murakami et al., 2007). It also displays antimicrobial, antioxidant, and chemopreventative effects on carcinogenesis models and inhibits mutagenesis and supresses the progression and migration of cancerous cells.

The dehydroergosterol is a naturally occurring fluorescent sterol analogue that mimics many of the properties of cholesterol. Recently it has been identified in Camembert and Gorgonzola cheeses fermented with Penicillium candidum; it inhibits cytokines and chemokines in microglial cells and reduced neurotoxicity in Neuro-2A cells (Ano et al., 2015). Based on the known biological/ medicinal properties of the compounds identified in the TE3 fraction, the synergistic effect of these components contributes to the anti-inflammatory activities

\section{CONCLUSION}

The TE3 fraction of ethyl acetate extract exhibited significant $(\mathrm{p}<0.05)$ anti-neuroinflammatory activity without imposing any cytotoxic effects on in vitro model 
of BV2 cells. The major lipid component, linoleic acid, identified in the fraction indicates that this mushroom is rich in unsaturated and essential fatty acids. The TE3 fraction gave a significant $(\mathrm{p}<0.05)$ dose-dependent NO reduction from $1-100 \mu \mathrm{g} / \mathrm{mL}$ treatments. The TE3 fraction downregulated the proinflammatory cytokines iNOS and COX2. It also upregulated the antiinflammatory gene (HO-1 and NQO-1) expressions and the corresponding Nrf2 pathway activation. The fraction has potent anti-inflammatory activities in an in vitro BV2 model and there may be synergistic effects among the constituents present as all the individual components in the fraction had anti-inflammatory activity. To our knowledge, this is the first report on an in vitro BV2 model based anti-neuroinflammatory property activity of $L$. rhinocerotis solvent based lipid enriched extract and its bioactive lipid component.

\section{ACKNOWLEDGEMENT}

This work was supported by University of Malaya High Impact Research MoE Grants, namely UM.C/625/1/HIR/MoE/SC/02 and UM.C/625/1/HIR/ $\mathrm{MOHE} / \mathrm{ASH} / 01$ (H-23001-G000008); and University of Malaya postgraduate grant (PG110-2012B).

\section{REFERENCES}

Ano Y, Kutsukake T, Hoshi A, Yoshida A, Nakayama H. Identification of a novel dehydroergosterol enhancing microglial anti-inflammatory activity in a dairy product fermented with Penicillium candidum. PloS One. 2015;10(3).

Babbar N, Oberoi HS, Uppal DS, Patil RT. Total phenolic content and antioxidant capacity of extracts obtained from six important fruit residues. Food Res. Int. 2011;44(1):391-396.

Chen WW, Zhang X, Huang WJ. Role of neuroinflammation in neurodegenerative diseases (Review). Mol Med Rep. 2016;13(4):3391-3396.

Cheng WL, Lii CK, Chen HW, Lin TH, Liu KL. Contribution of conjugated linoleic acid to the suppression of inflammatory responses through the regulation of the NF- $\kappa B$ pathway. J Agric Food Chem. 2004;52(1):71-78.

Diaz P, Jeong SC, Lee S, Khoo C, Koyyalamudi SR. Antioxidant and anti-inflammatory activities of selected medicinal plants and fungi containing phenolic and flavonoid compounds. Chin Med. 2012;7(1):26.
Dudhgaonkar S, Thyagarajan A, Sliva D. Suppression of the inflammatory response by triterpenes isolated from the mushroom Ganoderma lucidum. Int. immunopharmacol. 2009;9(11):1272-80.

Edmond J. Essential polyunsaturated fatty acids and the barrier to the brain. J Mol Neurosci. 2001;16(2-3):181-93.

Fritsche KL. The science of fatty acids and inflammation. Adv Nutr. 2015;6:293-301.

Gonzalez-Scarano F, Baltuch G. Microglia as mediators of inflammatory and degenerative diseases. Annu. Rev. Neurosci. 1999;22(1):219-240.

Günç Ergönül P, Akata I, Kalyoncu F, Ergönül B. Fatty acid compositions of six wild edible mushroom species. Sci. World J. 2013:163964.

Hensley K, Robinson KA, Gabbita SP, Salsman S, Floyd RA. Reactive oxygen species, cell signaling, and cell injury. Free Radic Biol Med. 2000;28(10):1456-62.

Innamorato NG, Rojo AI, García-Yagüe AJ, Yamamoto M, de Ceballos ML, Cuadrado A. The transcription factor Nrf2 is a therapeutic target against brain inflammation. J Immunol. 2008;181(1):680-689.

Jeong G, Lee D, Kim D, Jahng Y, Son J, Lee S, Kim Y. Neuroprotective and anti-inflammatory effects of mollugin via up-regulation of heme oxygenase-1 in mouse hippocampal and microglial cells. Eur J Pharmacol. 2011;654(3):226-234.

Kalac P. Chemical composition and nutritional value of European species of wild growing mushrooms: A review. Food Chem. 2009(1);113:9-16.

Kanagasabapathy G, Malek SNA, Kuppusamy UR, Sabaratnam V. Chemical composition and antioxidant properties of extracts of fresh fruiting bodies of Pleurotus sajor-caju (Fr.) Singer. J Agric Food Chem. 2011;59(6):26182626.

Lau BF, Abdullah N, Aminudin N, Lee HB, Tan PJ. Ethnomedicinal uses, pharmacological activities, and cultivation of Lignosus spp. (tiger's milk mushrooms) in Malaysia - A review. J Ethnopharmacol. 2015;169:441-458.

Lee JY, Jang YW, Kang HS, Moon H, Sim SS, Kim CJ. Antiinflammatory action of phenolic compounds from Gastrodia elata root. Arch. Pharm. Res. 2006;29(10):849-58.

Lee JY, Lee HJ, Jeong JA, Jung JW. Palmitic acid inhibits inflammatory responses in lipopolysaccharide-stimulated mouse peritoneal macrophages. Orient Pharm Exp Med. 2010;10(1):37-43. 
Lee ML, Tan NH, Fung SY, Tan CS, Ng ST. The antiproliferative activity of sclerotia of Lignosus rhinocerus (Tiger Milk Mushroom). Evid-Based Compl Altern Med. 2012. doi:10.1155/2012/697603

Lim EJ, Kang HJ, Jung HJ, Kim KH, Lim CJ, Park EH. Antiinflammatory, anti-angiogenic and anti-nociceptive activities of 4-hydroxybenzaldehyde. Biomol Ther. 2008;16(3):231-6.

Liu YX, Zhu XL, Chen YH, Guo F, Shen M, Chen ZG, Xu W, Chen DY, Tao ZH. Metabolomic profiles in prostate cancer cells progression. Chin J Anal Chem. 2011; 39(305):e11.

Ma Q. Role of Nrf2 in oxidative stress and toxicity. Ann Rev Pharmacol Toxicol. 2013;53:401-426.

McManus RM, Heneka MT. Role of neuroinflammation in neurodegeneration: new insights. Alzheimer's Res Ther. 2017; 9(14). doi: 10.1186/s13195-017-0241-2

Murakami Y, Hirata A, Ito S, Shoji M, Tanaka S, Yasui T, Machino M, Fujisawa S. Re-evaluation of cyclooxygenase2-inhibiting activity of vanillin and guaiacol in macrophages stimulated with lipopolysaccharide. Anticanc. Res. 2007;27(2):801-7.

Musolino C, Allegra A, Innao V, Allegra AG, Pioggia G, Gangemi S. Inflammatory and anti-inflammatory equilibrium, proliferative and antiproliferative balance: the role of cytokines in multiple myeloma. Mediators Inflam. 2017. doi: $10.1155 / 2017 / 1852517$

Nallathamby N, Lee GS, Raman J, Malek SNA, Vidyadaran S, Naidu M, Kuppusamy UR, Sabaratnam V. Identification and in vitro evaluation of lipids from sclerotia of Lignosus rhinocerotis for antioxidant and anti-neuroinflammatory activities. Nat Prod Commun. 2016;11(10):1485-1490.

Nallathamby N, Phan CW, Seow SLS, Baskaran A, Lakshmanan H, Abd Malek SN, Sabaratnam V. A status review of the bioactive activities of tiger milk mushroom Lignosus rhinocerotis (Cooke) Ryvarden. Front Pharmacol. 2018. doi:10.3389/fphar.2017.00998

Oh YT, Lee JY, Lee J, Lee JH, Kim JE, Ha J, Kang I. Oleamide suppresses lipopolysaccharide-induced expression of iNOS and COX-2 through inhibition of NF- $\mathrm{KB}$ activation in BV2 murine microglial cells. Neurosci Lett. 2010;474(3):148-53.

Ozcelik O, Algul S. Nitric oxide levels in response to the patients with different stage of diabetes. Cell Mol Biol. 2017;63(1):49-52.

Phan CW, David P, Tan YS, Naidu M, Wong KH, Kuppusamy UR, Sabaratnam V. Intrastrain comparison of the chemical composition and antioxidant activity of an edible mushroom,
Pleurotus giganteus, and its potent neuritogenic properties. Sci World J. 2014. doi: 10.1155/2014/378651

Rajeswari G, Murugan M, Mohan VR. GC-MS analysis of bioactive components of Hugonia mystax L.(Linaceae). Res J Pharm Biol Chem Sci. 2012;3(4):301-308.

Seow SLS, Eik LF, Naidu M, David P, Wong KH, Sabaratnam V. Lignosus rhinocerotis (Cooke) Ryvarden mimics the neuritogenic activity of nerve growth factor via MEK/ ERK1/2 signaling pathway in PC-12 cells. Sci Rep. 2015; 5:16349. doi:10.1038/srep16349

Sharma N, Samarakoon KW, Gyawali R, Park YH, Lee SJ, Oh SJ, Lee TH, Jeong DK. Evaluation of the antioxidant, antiinflammatory, and anticancer activities of Euphorbia hirta ethanolic extract. Molecules. 2014;19(9):14567-81.

Tan SW, Ramasamy R, Abdullah M, Vidyadaran S. Inhibitory effects of palm $\alpha-, \gamma$ - and $\delta$-tocotrienol on lipopolysaccharideinduced nitric oxide production in BV2 microglia. Cell Immunol. 2011;271(2):205-209.

Wohl MG, Goodhart RS. Modern Nutrition in Health and Disease. Academic Medicine. 1960;35(5):463.

Xu W, Zhang F, Luo Y, Ma L, Kou, X, Huang K. Antioxidant activity of a water-soluble polysaccharide purified from Pteridium aquilinum. Carbohydr. Res. 2009; 344(2):217-222.

Zhao G, Etherton TD, Martin KR, Vanden Heuvel JP, Gillies PJ, West SG, Kris-Etherton PM. Anti-inflammatory effects of polyunsaturated fatty acids in THP-1 cells. Biochem Biophy Res Comm. 2005;336(3):909-917. Chen WW, Zhang X, Huang WJ. 2016. Role of neuroinflammation in neurodegenerative diseases (Review). Mol Med Rep. 13:3391-3396.

Received for publication on $02^{\text {nd }}$ August 2018 Accepted for publication on $01^{\text {st }}$ February 2019 